\title{
Osoby z chorobami psychicznymi na rynku pracy
}

\section{People with mental disorders on the job market}

\section{Streszczenie:}

Praca jest jedną z podstawowych form działalności ludzkiej. Niestety, aż 95\% pracodawców nie widzi możliwości zatrudnienia osób chorych psychicznie. Szczególnie dotyczy to osób chorych na schizofrenię, którym ciężko znaleźć pracę na jakimkolwiek stanowisku. Wynikać to może ze stygmatyzacji osób chorych psychicznie lub z wewnętrznych przyczyn tkwiących $\mathrm{w}$ danej osobie. Zatrudnienie pracownika z chorobą psychiczną niesie ze sobą nie tylko zagrożenia, ale także korzyści dla pracodawcy. Dla osób z chorobą psychiczną praca jest natomiast źródłem leków, ale także radości. Ma ona istotne znaczenie dla stabilizacji zdrowia psychicznego.

Słowa kluczowe: choroba psychiczna, zaburzenia psychiczne, praca

\begin{abstract}
:
The work is one of the basic forms of human activity. Even 95\% employers do not see the possibility of employment for people with mental illness. Especially for people with schizophrenia, which is hard to find a job in any position. This may be due to the stigmatization of the mentally ill or internal causes inherent in the person. Employment of an employee with a mental illness carries with is not only threats, but also benefits the em-
\end{abstract}


Emilia Trzcińska - Osoby z chorobami psychicznymi...

ployer. For people with mental illness while work is a source of fears, but also joy. It is important to stabilize mental health.

Key words: mental disease, mental disorder, work

\section{Wstęp}

Osoby chore psychicznie przez większość społeczeństwa odbierane są krytycznie. Wynikać to może zarówno z historii, jak i współcześnie kształtowanych systemów światopoglądowych. Stygmatyzacja dotyczy prawie wszystkich chorych z zaburzeniami psychicznymi. W większym stopniu dotyka to jednak osób cierpiących na zaburzenia psychotyczne ${ }^{1}$. Coraz więcej osób choruje na depresję, co powoduje mniejszy stopień stygmatyzacji. Światowa Organizacja Zdrowia przewiduje, że przed 2030 rokiem depresja będzie jedną z głównych przyczyn skracania się długości życia. Profesor Martin Prince z King's College London podkreśla, iż osoby cierpiące na ciężką depresję muszą najczęściej zrezygnować z pracy. Ponadto związane jest to z większymi wydatkami na zasiłki dla bezrobotnych oraz chorobowe. Podstawą stygmatyzacji są procesy percepcyjne, które prowadzą na początku do ocen, a następnie do kategoryzacji na „lepszych” i "gorszych” czy na „normalnych” i „nienormalnych”. Duże znaczenie dla procesu stygmatyzacji, a zatem dla kształtowania społecznych interakcji piętnowanej jednostki mają przy tym określone parametry samego znaku. Są to: jakość estetyczna przypisywana danej osobie, odpowiedzialność za jego zaistnienie (sprawstwo), kierunek możliwych zmian, wpływ stygmatu na zdolności komunikowania się danej jednostki, a także reakcje emocjonalne wzbudzane przez stygmaty w otoczeniu. Skutki stygmatyzacji osób chorych psychicznie są trudne do ocenienia. Jednak może to prowadzić do społecznego wykluczenia i izolacji tych osób, co z kolei zmniejsza szansę na samorealizację.

\footnotetext{
${ }^{1}$ E. Dziwota, Stygmatyzacja osób chorych psychicznie, „Current Problems of Psychiatry" 2014, t. 15, nr 1, s. 18.
} 
To społeczne wykluczenie może dotyczyć bardzo wielu dziedzin, takich jak relacje $\mathrm{z}$ sąsiadami, ze znajomymi, z rodziną, szanse znalezienia partnera życiowego, uczestnictwo w życiu publicznym, możliwość kształcenia się, znalezienia mieszkania czy pracy adekwatnej do zdobytych kwalifikacji2

\section{Badania}

W 2012 roku zostały przeprowadzone badania o zdrowiu psychicznym Polaków przez Centrum Badania Opinii Społecznej. Dwanaście procent badanych stwierdziło, że największą obawę pośród wszystkich chorób wywołuje w nich choroba psychiczna. Na pytanie: jak, ogólnie rzecz biorąc, ocenia Pan(i) stan swojego zdrowia psychicznego osoby badane stwierdziły, że ich zdrowie psychiczne jest u 30\% bardzo dobre, u 54\% dobre, u 14\% osób takie sobie, natomiast złe u 1\% osób. Trudno powiedzieć zaznaczyło również 1\% badanych. Zdrowie, według Światowej Organizacji Zdrowia, to pełen dobrostan fizyczny, umysłowy i społeczny, a nie tylko całkowity brak choroby lub kalectwa. W tym samym badaniu zadane było pytanie: Jakie warunki życia moga być, Pana(i) zdaniem, szczególnie szkodliwe dla zdrowia psychicznego ludzi i zwiększać ryzyko zachorowania na choroby psychicz$n e$ ? Sześćdziesiąt pięć osób zaznaczyło, że największy wpływ ma brak pracy i bezrobocie. W tym samym roku przeprowadzone zostały badania o stosunku do osób chorych psychicznie. Osoby, które zostały zbadane najbardziej niechętnie reagują na osoby, które kiedyś chorowały psychicznie i leczyły się w szpitalu psychiatrycznym, a miały zostać opiekunem (79\%) lub nauczycielem (71\%) ich dzieci. „Nieco mniej osób sprzeciwiłoby się temu, by pacjent szpitala psychiatrycznego miał zostać ich lekarzem (62\%), burmistrzem lub wójtem w ich gminie (59\%), szefem w pracy (46\%), bądź proboszczem w parafii (44\%). W przypadku pięciu pozostałych ról postawy wyrażające przyzwolenie są częstsze niż te nacechowane sprzeciwem. Zdecydowana większość badanych nie miałaby nic przeciwko temu, gdyby osoba,

\footnotetext{
2 P. Świtaj, Piętno choroby psychicznej, „Postępy Psychiatrii i Neurologii” 2005, t. 14 , nr 2, s. 137-144.
} 
Emilia Trzcińska - Osoby z chorobami psychicznymi...

które kiedyś leczyła się psychiatrycznie, była ich sąsiadem (82\%), kolegą w klasie lub grupie studenckiej (76\%) bądź bliskim współpracownikiem (68\%). Mniej więcej połowa zgodziłaby się, aby taka osoba była ich współlokatorem na wczasach (51\%), a także synową lub zięciem, a więc członkiem rodziny $(45 \%)^{3}$. Problemem dla badanych jest pełnienie przez osoby chore psychicznie ról zawodowych. Istotą roli zawodowej są oczekiwania środowiska, szczególnie środowiska zawodowego, względem obowiązków i uprawnień pracownika.

\section{Terminologia}

Czym jest zatem choroba psychiczna? W historii ludzkości pojęcie zachowań nienormalnych ulegało zmianie. Starożytni Grecy szanowali osoby z darem „jasnowidzenia”. Dziś takie osoby uważa się najczęściej za schizofreników. Leczenie między innymi odbywa się w szpitalach psychiatrycznych. Pierwsze szpitale psychiatryczne powstały w XVII wieku. Miały zapewnić przetrwanie osobom bezdomnym i bezrobotnym. Wśród nich znajdowały się osoby z chorobami psychicznymi, które izolowano i traktowano znacznie gorzej. Przykładowo, pacjentów szpitala St. Mary's of Bethlehem w Londynie przykuwano łańcuchami do ściany.

Pojęcie nienormalności nie jest dokładnie zdefiniowane. Nie oznacza to jednak, że zjawisko to nie istnieje. Podstawą stwierdzenia działań nienormalnych jest siedem cech, takich jak: cierpienie danej osoby, nieprzystosowanie, irracjonalność, nieprzewidywalność i brak kontroli, rzadkość i niekonwencjonalność, dyskomfort obserwatora oraz naruszanie norm ${ }^{4}$.

Ze względu na to, że ocena nienormalności jest oceną społeczną, nie ma zgodności co do tego, kto jest nienormalny, oraz jakie myśli i działania kwalifikują się do uznania za nienormalne. Społeczeństwo czasami się myli, nazywając

\footnotetext{
${ }^{3}$ M. Omyła-Rudzka, Stosunek do osób chorych psychicznie, Warszawa 2012, s. 7-8.

${ }^{4}$ M. E. P. Seligman, E. F. Walker, D. L. Rosenhan, Psychopatologia, Poznań 2003, s. 43.
} 
kogoś nienormalnym, tak samo jak mylą się obserwatorzy, nawet gdy są wykwalifikowanymi diagnostami".

Podobnie trudno jest zdefiniować pojęcie choroby psychicznej. Termin „choroby psychicznej” najprawdopodobniej pojawił się na przełomie XVIII i XIX wieku. W najnowszej wersji klasyfikacji DSM-V, która obowiązuje w Stanach Zjednoczonych oraz klasyfikacji ICD-10 wprowadzoną przez Światową Organizację Zdrowia, zastąpiono termin „choroba psychiczna” określeniem „zaburzenie”. Przyczyną tego stanu rzeczy jest uniknięcie wątpliwości dotyczących terminu „choroba”. Problem nazewnictwa nie została jednak rozwiązana. Według Słownika języka polskiego PWN choroby psychiczne to: „zaburzenia w psychice zakłócające stosunki z innymi ludźmi, niosące ze sobą jakieś ograniczenia lub stwarzające zagrożenie"6. Wielki słownik medyczny podaje następującą definicję choroby psychicznej:

\begin{abstract}
...termin zbiorczy obejmujący wszelkie zaburzenia typu psychotycznego, tzn. takie, w których występują objawy psychotyczne (omamy, urojenia, ciężkie zaburzenia nastroju, emocji i in.). W węższym znaczeniu tego terminu choroba psychiczna jest synonimem psychozy. Jest to zaburzenie psychiczne w znacznym stopniu ograniczające wgląd, czyli poczucie choroby, zdolność radzenia sobie ze zwykłymi wymaganiami życia lub utrzymania właściwego kontaktu z rzeczywistością. Obraz kliniczny psychozy charakteryzuje się jakościowymi zmianami chorobliwymi w zakresie myślenia, intelektu, świadomości, postrzegania, uczuć, napędu psychoruchowego i innych funkcji psychicznych, prowadzącymi niekiedy do znaczących zaburzeń zachowania w środowisku społecznym"7.
\end{abstract}

Szczególne znaczenie w historii podejmowanych prób zdefiniowania choroby psychicznej miał ruch antypsychiatryczny. Thomas Szasz traktuje chorobę psychiczną jako mit, a nie prawdziwą chorobę. Uważa on, że rzeczywistymi chorobami są wyłącznie stany odchylenia od norm anatomicznych i genetycznych. Dziś wiadomo, że to podejście

\footnotetext{
${ }^{5}$ S. Pużyński, Choroba psychiczna - problemy z definicja oraz miejscem $w$ diagnostyce i regulacjach prawnych, „Psychiatria Polska” 2007, t. XLI, nr 3, s. 303.

6 http://sjp.pwn.pl/sjp/choroby_psychiczne;2996691 (dostęp: 25.06.2016).

7 S. Pużyński, Choroba psychiczna..., op. cit., s. 304-305.
} 
Emilia Trzcińska - Osoby z chorobami psychicznymi...

było błędne ${ }^{8}$. Ustawa o ochronie zdrowia psychicznego mówi o osobach z zaburzeniami psychicznymi.

Ilekroć przepisy niniejszej ustawy stanowią o:

1. Osobie z zaburzeniami psychicznymi, odnosi się to do osoby:

a) chorej psychicznie (wykazującej zaburzenia psychotyczne),

b) upośledzonej umysłowo,

c) wykazującej inne zakłócenia czynności psychicznych, które zgodnie ze stanem wiedzy medycznej zaliczane są do zaburzeń psychicznych, a osoba ta wymaga świadczeń zdrowotnych lub innych form pomocy i opieki niezbędnych do życia w środowisku rodzinnym lub społecznym.

W ustawie tej brak jest definicji „choroby psychicznej” co może być przyczyna nadużyć.

\section{Osoba z chorobą psychiczną jako pracownik}

Rozważania na temat pracy spotkać można w rozprawach filozoficznych, etycznych, ekonomicznych, socjologicznych, historycznych, etnologicznych, prakseologicznych, medycznych, psychologicznych czy pedagogicznych. W języku potocznym praca występuje najczęściej w dwóch znaczeniach:

1. czynnościowym (funkcjonalnym) - oznacza pewną formę działania,

2. rzeczowym (przedmiotowym) - oznacza wynik, efekt, dzieło czy wytwór jakiegoś działania.

Pojęcie pracy ma wiele definicji. W fizyce praca jest uznawana za przesunięcie siły wzdłuż drogi. W sensie biologicznym to ruch oraz reakcje chemiczne jakie odbywają się w żywym organizmie. W psychologii praca to forma systematycznej aktywności umysłowej, którą kieruje motywacja do osiągnięcia określonego celu. Prawo definiuje pracę jako konsekwencję stosunku umownego między pracodawcą a pracobiorcą. W socjologii praca jest celową czynnością, która ma

8 A. Kapusta, Pojęcie choroby psychicznej w fenomenologicznej perspektywie, „Studia Metodologiczne" 2013, nr 30, s. 45. 
służyć do zaspokojenia podstawowych potrzeb ludzkich. Abraham Maslow twierdził, że człowiek działa pod wpływem najsilniejszych potrzeb, które tworzą naturalną hierarchię. Wprowadzona przez niego hierarchia potrzeb składa się z sześciu grup potrzeb ułożonych według ważności. Najważniejsze są potrzeby biologiczne, które znajdują się na samym dole. Potrzeby te to: potrzeba pokarmu, wody, tlenu, uwolnienia się od napięcia czy odpoczynku. Następną potrzebą jest potrzeba bezpieczeństwa. Trzecią potrzebą jest potrzeba przynależności i miłości, a więc potrzeba kochania i bycia kochanym, a także potrzeba bycia akceptowanym. Potrzeba szacunku zawiera w sobie potrzebę pewności siebie oraz szacunku i uznania ze strony innych. Jako następna $w$ hierarchii jest potrzeba wykorzystania swojego potencjału, czyli samorealizacja. Natomiast na samym szczycie Abraham Maslow umieścił samotranscendencję, która jest potrzebą wyjścia poza własną przyjemność. Według autora potrzeby z niższych szczebli hierarchii dominują motywację jednostki do momentu, kiedy zostaną zaspokojone. W dzisiejszych czasach coraz częściej zaniedbujemy podstawowe potrzeby biologiczne na rzecz potrzeb stojących wyżej9.

Powszechnie uznawaną definicją pracy jest ta, w której praca jest postrzegana jako:

działalność człowieka zmierzająca do wytworzenia dóbr i usług, które mają mu zapewnić warunki egzystencji i rozwoju. Praca w rozwoju ludzkości podlegała ewolucji. Zmieniały się warunki pracy oraz stosunki międzyludzkie, w których się odbywała. W pierwszych etapach cywilizacji istotą pracy było zapewnienie możliwości przeżycia, później - wytworzenia i przechowania nadwyżek, co dawało możliwość wymiany i celowego rozwoju gospodarczego. W wyniku rozwoju cywilizacyjnego praca stawała się coraz mniej uciążliwa i coraz bardziej bezpieczna, poprawiły się stosunki pracy (stały się mniej konfliktowe i mniej asymetryczne), a także wzrastało wynagrodzenie za pracę (osłabły tendencję do wyzysku). Obecnie powoli zanika tradycyjna forma zatrudnienia pracowników, ponieważ gwałtowniej niż kiedykolwiek zmienia się struktura popytu na pracę. Dynamika zmian w stosunkach pracy nabrała

${ }_{9}^{9}$ P. G. Zimbardo, R. L. Johnson, V. McCann, Psychologia. Kluczowe koncepcje. Podstawy psychologii, Warszawa 2011, s. 68-69. 
Emilia Trzcińska - Osoby z chorobami psychicznymi...

obecnie zawrotnego tempa. To jeden z najbardziej charakterystycznych „zna-

ków" naszego czasu ${ }^{10}$.

Do pracy potrzebna jest motywacja, która zaangażowana jest w inicjowanie, ukierunkowywanie i utrzymywanie fizycznych i psychicznych aktywności. Psychologia wyróżnia dwie rodzaje motywacji: wewnętrzną i zewnętrzną. Ta pierwsza pochodzi z wnętrza człowieka, czyli z cech osobowościowych i zainteresowań. Nie podejmuje ona działań tylko i wyłącznie dla zewnętrznej nagrody. Druga motywacja opiera się właśnie na zewnętrznych skutkach. Pochodzi więc z zewnątrz. David McClelland określił na podstawie ludzkich potrzeb trzy rodzaje motywacji ukierunkowanej na:

- potrzebę przynależności,

- potrzebę władzy oraz,

- potrzebę osiągnięć.

Na całym świecie na choroby psychiczne choruje ponad 350 milionów ludzi. Badania z 2010 roku pozwalają na stwierdzenie, że w Polsce objętych opieką ambulatoryjną było 1,5 miliona osób. Natomiast w całodobowych oddziałach psychiatrycznych leczono około 200 tysięcy chorych.

Jedynie $17 \%$ tych osób jest aktywnych zawodowo. Praca zawodowa dla osób chorych psychicznie może mieć istotne znaczenie dla stabilizacji ich stanu psychicznego. Objawy chorobowe mają wpływ na funkcjonowanie zawodowe. Wynikiem tego może być obniżona wydajność pracy, problemy z komunikacją ze współpracownikami i klientami, obniżone tempo pracy, zaburzenia koncentracji, a to z kolei może wpływać na ryzyko urazów i wypadków w miejscu pracy.

10 Z. Ratajczak, Psychologia pracy i organizacji, Warszawa 2007, s. 42. 
Wykres 1. Wpływ choroby psychicznej na pracę

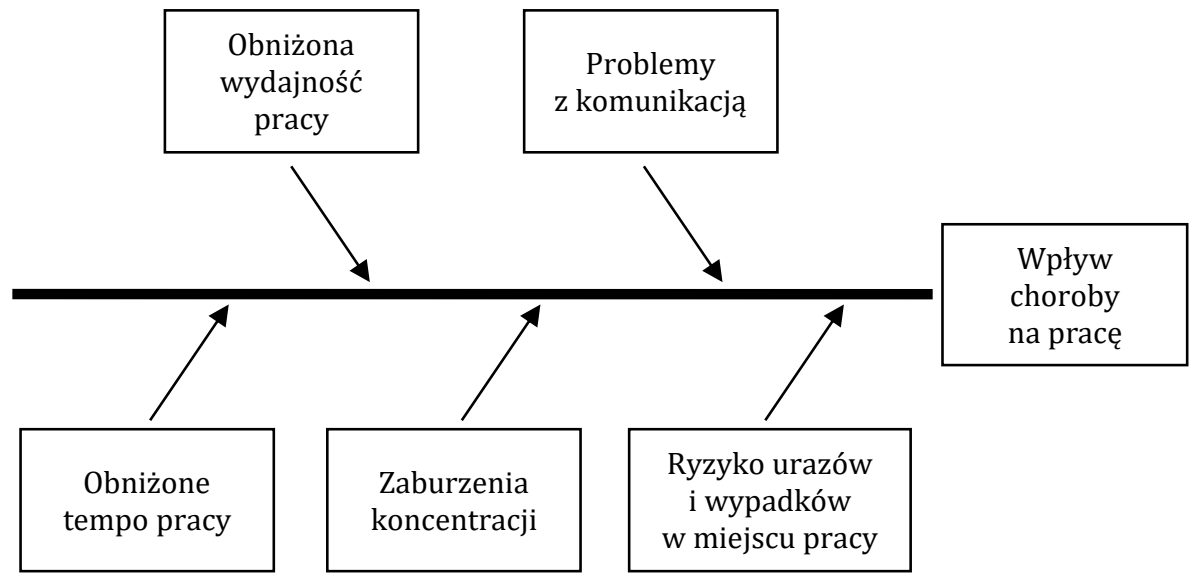

Źródło: opracowanie własne.

Wpływ zaburzeń psychicznych na pracę jest niekorzystny, mimo to, uważa się, że możliwość uczestniczenia w rynku pracy, które przyczynia się do poczucia przynależności społecznej, jest niezbędna do utrzymania zdrowia psychicznego i dobrego samopoczucia jednostki. Jak zauważa Kaszyński:

aktywność zawodowa osób po głębokich kryzysach psychicznych - jest najbardziej pożądanym wynikiem leczenia i rehabilitacji, który jest powiązany z obniżeniem poziomu objawów chorobowych, ograniczeniem liczby i czasu hospitalizacji psychiatrycznych oraz ze znaczną poprawą funkcjonowania społecznego. Równie istotna jest konstatacja, że dla samych chorych praca jest synonimem zdrowia". Osoby z zaburzeniami psychicznymi SĄ grupą społeczną najbardziej narażoną na wykluczenie z rynku pracy ${ }^{11}$.

Anthony Giddens zauważył, że 1/4 osób, które wychodzą ze szpitali psychiatrycznych są osobami bezdomnymi, co z kolei wynikać może z braku dla tych osób pracy. Mówi się o czterech podstawowych przyczynach wykluczenia z rynku pracy osób chorych psychicznie. Jest to:

11 A. Cybula-Fujiwara, D. Merecz-Kot, J. Walusiak-Skorupa, A. Marcinkiewicz, M. Wiszniewska M., Pracownik z chorobq psychiczna - możliwości i bariery w pracy zawodowej, „Medycyna Pracy” 2015, t. 66, nr 1, s. 65. 
Emilia Trzcińska - Osoby z chorobami psychicznymi...

1. zbyt mała liczba miejsc pracy,

2. stygmatyzacja i dyskryminacja osób chorych psychicznie,

3. długotrwała zależność od pasywnych form pomocy społecznej,

4. zależność od rodziców ${ }^{12}$.

Hubert Kaszyński podaje rozkład zapotrzebowania na miejsca pracy w grupie osób chorujących psychicznie. Przedstawia się on następująco:

- $\quad 20 \%$ osób jest zdolnych do pracy w warunkach konkurencyjnych;

- $\quad 60 \%$ osób wymaga różnorodnych form wspieranego zatrudnienia, w tym połowa jest zdolna do pracy w urynkowionych przedsiębiorstwach społecznych, natomiast pozostała część chorych wymaga zróżnicowanych rozwiązań pracy obejmujących również formy rehabilitacji społeczno-zawodowej;

- $\quad 20 \%$ osób wymaga zindywidualizowanej rehabilitacji społecznej w formie ośrodków pobytu dziennego, grup zorientowanych na organizację czasu wolnego, itp.

Praca dla osób chorych psychicznie, jak wcześniej wspomniano, ma istotne znaczenie. Warto skupić się na pozytywach i zdolnościach tych osób, ponieważ to na jakim stanowisku zostanie zatrudniona taka osoba zależy od stopnia wyzdrowienia i aktualnego samopoczucia. Pracodawca zyskuje z zatrudnienia osoby ze znacznym lub umiarkowanym stopniem niepełnosprawności, a do tych należą osoby z chorobą psychiczną, między innymi: dofinansowanie wynagrodzenia i składek na ubezpieczenie emerytalne; zwrot kosztów szkolenia tych osób - nawet do 80\%; zmniejszenie wpłat na PEFRON czy zyskanie wizerunku firmy wrażliwej społecznie. Najważniejszą korzyścią jest zyskanie zaangażowanego i lojalnego pracownika13.

\footnotetext{
12 H. Kaszyński, Osoby chore psychicznie jako grupa beneficjentów organizacji pozarzadowych świadczacych usługi na rynku pracy, Warszawa 2006, s. 6.

$13 \mathrm{http}: / /$ www.centrumcsr.pl/pliki/chorzy_psychicznie_insert.pdf (dostęp: 25.06.2016).
} 
Wykres 2. Korzyści z zatrudnienia osoby z chorobą psychiczną

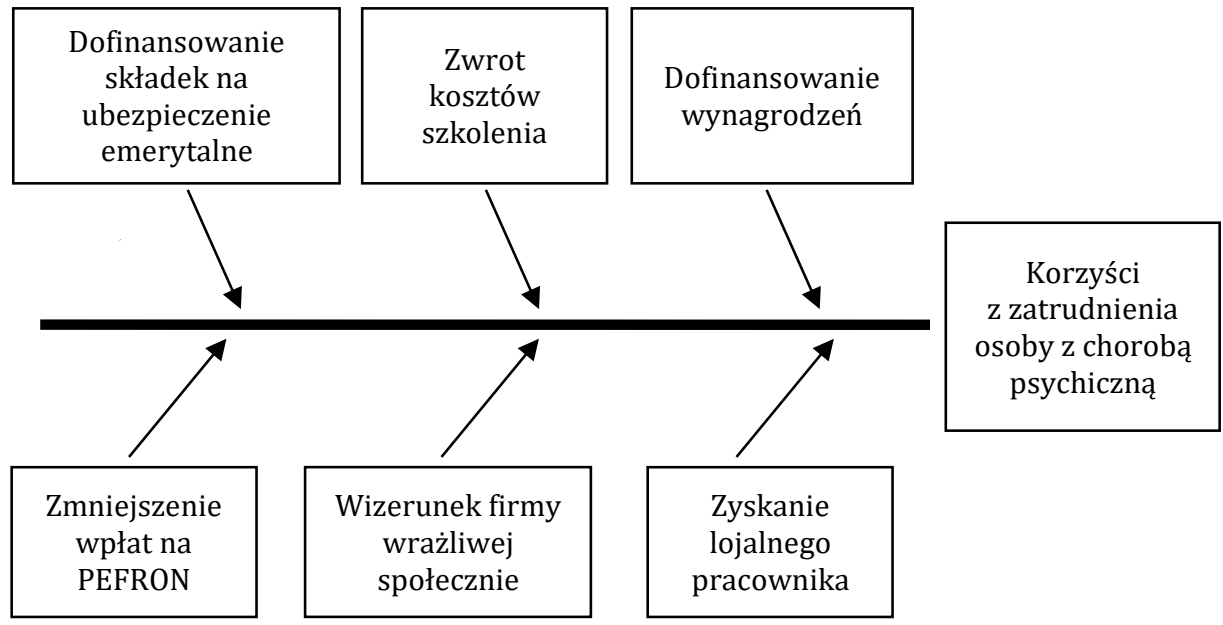

Źródło: opracowanie własne.

Na całym świecie prowadzone są programy wspierające osoby chore psychicznie w zatrudnieniu. Jednak dane Głównego Urzędu Statystycznego wskazują, iż poziom zatrudnienia osób z różnymi niepełnosprawnościami pozostaje bardzo niski. Osoby chore psychicznie bardzo często pracują okresowo. Praca może być źródłem dużego stresu, co z kolei może prowadzić do nawrotów choroby. Utrata pracy i problemy z ponownym jej znalezieniem mogą prowadzić do rezygnacji z szukania i podjęcia zatrudnienia.

Wykluczenie społeczne w wymiarze aktywności zawodowej, a w efekcie również w wymiarze ekonomicznym, ujawnia się w przypadku osób chorujących psychicznie nie tylko poprzez trudności w znalezieniu pracy, ale też poprzez niski status zawodów, których wykonywanie zleca się osobom niepełnosprawnym - często są to stanowiska niewymagające specjalistycznej wiedzy i umiejętności, takie jak stróż czy sprzątacz. Problem degradacji zawodowej szczególnie mocno dotyka osoby chorujące psychicznie, które wcześniej zajmowały wysokie stanowiska ${ }^{14}$.

14 Rzecznik Praw Obywatelskich, Wsparcie osób chorujacych psychicznie. Analiza i zalecenia, „Biuletyn Rzecznika Praw Obywatelskich” 2014, nr 8, s. 6. 
Emilia Trzcińska - Osoby z chorobami psychicznymi...

\section{Środowisko}

W latach siedemdziesiątych powstała pedagogika Gestalt, jako jeden z rodzajów pedagogiki alternatywnej. Twórcy tej pedagogiki przeciwstawiają się dehumanizacji stosunków międzyludzkich czy uprzedmiotowieniu jednostki ludzkiej. Pedagogika Gestalt podkreśla, iż:

1. człowiek jest $w$ istocie organizmem godnym zaufania,

2. człowiek niesie w sobie ogromny potencjał możliwości, do których realizacji muszą być stworzone odpowiednie warun$\mathrm{ki}$,

3. człowiek jest istotą społeczną,

4. człowiek jest aktywny sam z siebie i zmienia się dzięki własnej aktywności i jego interakcjom z otoczeniem,

5. każda jednostka zmierza do wielostronnego rozwoju swoich możliwości i zdolności,

6. zachowania człowieka można zrozumieć tylko w ich całości.

Ważne jest również to, że wśród głównych celów tego nurtu wymienia się przede wszystkim: odnalezienie siebie, własnej tożsamości, samorealizacja, eliminacja blokad wewnętrznego rozwoju, osobisty rozwój, rozwój wspólnego ludziom potencjału, przygotowanie jednostki do rozpoznawania i realizacji własnego potencjału rozwojowego, odpowiedzialność za samego siebie, rozpoznawanie osobistych potrzeb i zainteresowań i ich dalsze rozwijanie, koncentrowanie się na „tu i teraz”. Wszystko to ma ogromne znaczenie dla jakości i satysfakcji z życia. Praca ma pomóc w odnalezieniu własnego potencjału. Ma także pomóc w zaspokojeniu naszych potrzeb ${ }^{15}$.

Każdy człowiek należy do określonej grupy kulturowej i jest uczestnikiem życia społecznego. Człowiek poprzez wrastanie w określone środowisko kształtuje samego siebie. Dlatego coraz częściej pedagogika i psychologia podkreślają ścisły związek człowieka z ota-

15 J. Potrzebny, Pedagogika Gestalt, „Rocznik Edukacji Alternatywnej” 2003, nr 1, s. $111-135$. 


\section{czającym go środowiskiem. Rodzina wprowadza dziecko w świat wartości społecznych.}

Jednostka spostrzega swoje otoczenie w określony sposób, dokonuje interpretacji tego, co spostrzega i w rezultacie podejmuje różnorodne działania, służące z jednej strony zaspokajaniu jej osobistych potrzeb, a z drugiej spełnianiu oczekiwań i wymagań otoczenia. Oczekiwania te nie zawsze ujawniane są wprost, bardzo często są ukryte, np. w tym, jak zorganizowana jest przestrzeń i czas, jakie przedmioty są dostępne, a jakie nie, jak zachowują się ludzie pozostający z nią w różnego typu relacjach emocjonalnych i zadaniowych. Oczekiwania te mają formujący wpływ na jej zachowanie, ale jednocześnie zachowania jednostki wpływają formująco na kształt tego, co ją otacza i na to, jakie oczekiwania formułują ludzie względem niej. Relacja jest więc wzajemna, a wpływ obopólny. Z drugiej strony zachowania jednostki wyznaczane są poziomem jej dojrzałości biologicznej, zmieniającym się wraz z wiekiem i także wpływającym na to, jak spostrzega, przeżywa i ocenia otaczającą ją rzeczywistość, i do wchodzenia w jakiego typu relacje $\mathrm{z}$ otoczeniem jest gotowa ${ }^{16}$.

\section{Podsumowanie}

Praca stanowi 32\% naszego życia. Jest jedną z podstawowych form działalności człowieka. Służy zaspokajaniu różnych potrzeb. Dlatego jest tak istota dla każdego, a w szczególności dla osób chorych psychicznie.

Podejmując próby rozwiązywania problemu braku pracy wśród osób chorujących psychicznie należy podkreślić, iż problem ten determinowany jest nie tylko faktem choroby psychicznej, ale częstokroć poważnymi dysfunkcjami osobowościowymi, które przejawiają się stanem niedojrzałości społecznej, niskim poziomem kompetencji społecznych lub trudnościami $\mathrm{w}$ budowaniu stabilnych relacji społecznych ${ }^{17}$.

Wynikać może także ze stygmatyzacji i dyskryminacji środowiska zewnętrznego. Sytuacja ta może ulec częściowej zmianie poprzez zrozumienie zachowań i emocji osób chorych psychicznie.

\footnotetext{
16 A. Brzezińska A., Społeczna psychologia rozwoju, Warszawa 2010.

17 H. Kaszyński, Osoby chore psychicznie..., op. cit., s. 6.
} 
Emilia Trzcińska - Osoby z chorobami psychicznymi...

\section{Bibliografia:}

American Psychiatric Association, Diagnostic and Statistical Manual of Mental Disorders (wyd. 5), Washinghton 2013.

Boguszewski R., Zdrowie psychiczne Polaków, Warszawa 2012.

Brzezińska A., Społeczna psychologia rozwoju, Warszawa 2010.

Cybula-Fujiwara A., Merecz-Kot D., Walusiak-Skorupa J., Marcinkiewicz A., Wiszniewska M., Pracownik z chorobq psychiczna - możliwości i bariery w pracy zawodowej, „Medycyna Pracy” 2015, t. 66, nr 1, s. 57-69.

Dziwota E., Stygmatyzacja osób chorych psychicznie, „Current Problems of Psychiatry" 2014, t. 15, nr 1, s. 18-23.

Kapusta A., Pojęcie choroby psychicznej w fenomenologicznej perspektywie, „Studia Metodologiczne” 2013, nr 30.

Kaszyński H., Osoby chore psychicznie jako grupa beneficjentów organizacji pozarządowych świadczących usługi na rynku pracy, Warszawa 2006.

Międzynarodowa Statystyczna Klasyfikacja Chorób i Problemów Zdrowotnych, Klasyfikacja zaburzeń psychicznych i zaburzeń zachowania w ICD-10. Badawcze kryteria diagnostyczne, Kraków-Warszawa 1998.

Międzynarodowa Statystyczna Klasyfikacja Chorób i Problemów Zdrowotnych, Klasyfikacja zaburzeń psychicznych i zaburzeń zachowania w ICD-10. Opisy kliniczne i wskazówki diagnostyczne, Kraków-Warszawa 2000.

Omyła-Rudzka M., Stosunek do osób chorych psychicznie, Warszawa 2012.

Potrzebny J., Pedagogika Gestalt, „Rocznik Edukacji Alternatywnej” 2003, nr 1, s. 111-135.

Pużyński S., Choroba psychiczna - problemy z definicjq oraz miejscem $w$ diagnostyce i regulacjach prawnych, „Psychiatria Polska” 2007, t. XLI, nr 3, s. 299-308.

Ratajczak Z., Psychologia pracy i organizacji, Warszawa 2007.

Rzecznik Praw Obywatelskich, Wsparcie osób chorujących psychicznie. Analiza i zalecenia, „Biuletyn Rzecznika Praw Obywatelskich” 2014, nr 8.

Seligman M. E. P., Walker E. F., Rosenhan D. L., Psychopatologia, Poznań 2003. Świtaj P., Piętno choroby psychicznej, „Postępy Psychiatrii i Neurologii” 2005, t. 14, nr 2, s. 137-144.

Zimbardo P. G., Johnson R. L., McCann V., Psychologia. Kluczowe koncepcje. Podstawy psychologii, Warszawa 2011. 


\section{Netografia:}

http://sjp.pwn.pl/sjp/choroby_psychiczne;2996691 (dostęp: 25.06.2016) http://www.centrumcsr.pl/pliki/chorzy_psychicznie_insert.pdf (dostęp: 25.06.2016) 